\title{
Legal Protection for Child Victims of Violence in Primary School in Palembang City
}

\author{
Austin Al Hariz, Nashriana, Vera Novianti \\ Law Program, Faculty of Law, Sriwijaya University, Palembang, South Sumatera \\ *corresponding author email:austinalhariz02@gmail.com, nashriana_zaks@yahoo.co.id, \\ novianti_vera@yahoo.com
}

\begin{abstract}
Violence to children can occur anywhere, including in the world of education. This research is the form of legal protection for child victims of violence in elementary schools and how to prevent legal protection against child victims of violence in primary schools. This research aims to know and explain the form of legal protection for victims of violence against children in schools. It is also to understand and explain lawful prevention in carrying out legal guardians for children's violence victims in schools. The research method in this research is descriptive analysis. The types of data in this study are primary and secondary data. Methods of data collection using field studies, literature studies, and documentation studies. Research locations are in several elementary schools in the city of Palembang. Forms of protection for child victims of violence in primary schools include rehabilitation efforts in an institution or outside the institution. These strategies are useful for restoring mental, physical, especially after experiencing intense trauma due to a criminal incident. Efforts to prevent child victims of violence in elementary schools, namely the school collaborating with parents in supervising students and children so that acts of violence committed by children in elementary schools do not happen again. Conclusion is Forms of protection for children who are victims of bullying: Rehabilitation efforts that are carried out within an institution or outside of an institution, these efforts are made to restore mental, physical, and other conditions after experiencing very deep trauma as a result of a criminal event he has experienced.
\end{abstract}

Keywords: legal protection, violence, elementary school, children, victims

\section{INTRODUCTION}

Children are also a human right as well as a gift from God Almighty, who always have to maintain their dignity, and inherent human rights since the child's improvement. Children need love and special guidance so that they can develop physically, mentally, and spiritually to their full potential. For this reason, legal protection for children is necessary against all forms of disturbance and order in a society that can harm children's development. Including child protection against all forms of neglect, violence, and exploitation [1]. Children are a mandate as well as a gift from God Almighty, which we must always protect because of their inherent dignity and rights as human beings that must be upheld [2]. Educational experts who have done a lot of research on educational levels agree and divide as follows [3].: a) children from birth to 12 years of age; b) adolescents from 12 to 14 years of age; c) youth from 14 to 25 years of age; d) adults after 25 to 60 years; and e) parents after being over 60 years old and beyond. Cyber bullying happens as follows [4]: (a) Flaming. Online "fights" using electronic messages with angry and vulgar language; (b) Harassment. Repeatedly sending offensive, rude, and insulting messages; (c) Cyberstalking. Repeatedly sending messages that include threats of harm or are highly intimidating; (d) Denigration. Sending or posting cruel gossip or rumors about a person to damage his or her reputation or friendships; \{e) Impersonation. Breaking into someone's account, posing as that person and sending messages to make the person look bad, get that person in trouble or danger, or damage that person's reputation or friendships; (f) Outing and Trickery. Sharing someone's secrets or embarrassing information online; (g) Exclusion. Intentionally excluding someone from an online group. The phenomenon of deviation in the world of education can be classified as an ordinary offense or a criminal act [5]. Violence against children can occur anywhere, including in the world of education. One way to prevent this is by introducing the importance of children's rights, and how the dangers of violence against children in educational settings, namely schools. Violence against children is an event of physical, mental, or sexual treatment of children who have not reached the age of 18 which is generally carried out by people who have responsibility for the welfare of the child, which is indicated by losses and threats to the health and welfare of the child [6]. Violent behavior carries physical, psychological and social risks for other people as well as violent behavior. Violent behavior does not only include 
physical aspects of action, but also includes verbal, psychological and symbolic violence or a combination of all of these aspects [7]. The magnitude of child abuse is alarming in our region. The largest number of child labour, abuse, prostitution and trafficking has been reported in India, Pakistan, Bangladesh, Bhutan and Nepal. The largest number of working children in the world, fulfilling the criteria of abuse resides in India [8]. A child who is raised full of violence will dull his heart from humanity. Children who are accustomed to being treated harshly will behave rudely to other parties [9].According to Sutanto, child abuse is the treatment of adults or older children by using their power or authority against a helpless child who should be the responsibility of the caregiver which results in suffering, suffering, disability, or death. Child abuse is more of a form of physical abuse with marks or wounds on the child's body. [10]. Violence against children is one of the most dominant cases and is found everywhere, almost in every place throughout the province. [11]. Violence against children of any kind, ranging from neglect, exploitation, discrimination to inhuman treatment will be recorded in their subconscious mind until they grow up even throughout their lives [12]. Protection of Indonesian children means protecting the potential of human resources and developing the whole Indonesian people, towards a just and prosperous society, spiritual material based on Pancasila and the 1945 Constitution [13]. This problem makes him a creature who loses direction and purpose. He has ambition, desire and demands wrapped in lust, but because of excessive desire, he fails to be controlled and educated, which causes the problems he faces to be more numerous and varied [14].Juvenile delinquency and crime never take place in a closed manner and do not proceed in a vacuum but take place in an interpersonal context. Therefore, this delinquency attitude or action can be organized or characteristic. In connection with all the factors listed above, delinquency can be grouped into four groups, namely[15].: (1) Individual Delinquency Namely, delinquency is a personal or individual symptom with characteristics of evil, caused by a predisposition and a tendency towards behavioral deviations (psychopathic, psychotic, pneumatic, asocial) which are exacerbated by social stimuli and cultural conditions.2. Siteional delinquency Namely, delinquency is committed by normal children, but they are often influenced by various situational forces, social stimuli, and environmental pressures, all of which have a pressing and coercive influence on the formation of children's behavior. 3. Systematic delinquency Namely, delinquency that has been stabilized in an organization (gang). All crimes are rationalized and justified by gang members so that the crimes become organized or become systematic in nature.4. Cumulative Delinquency. Namely the delinquency that has spread in almost all capitals, cities, even to the outskirts of villages. In essence, this delinquency is a product of cultural conflict. In North America, more than half a million youth under the age of 18 experience a Traumatic Brain Injury (TBI) that requires hospital-based care each year [1-4]. In the US and Canada, 50\% of all injuries that kill and disable youth involve a TBI, and less severe injuries most often occur during sport activities [5-6]. Studies with clinical samples show impairments associated with TBI that include short- and longterm burdens related to cognitive, emotional and social functioning [1,4-8] [16]. The results of the present study conducted in Vietnam showed that $9.0 \%$ of junior high school students reported their experience of being cyberbullied, and that experience of being cyberbullied was significantly associated with self- harm. In addition, parental acceptance showed a signifi- cant protective relationship by reducing the rates of self- harm and suicidal behaviors, including suicidal ideation, suicidal planning, and suicide attempts in a sample of ado- lescents from Hue city, Vietnam [17]. The research question of this research was what is the form of legal protection for victims of violence against children in elementary schools? The purpose of this research was to know and explain the form of legal protection for victims of violence against children in elementary schools.

\section{RESEARCH METHOD}

This research is sociological or empirical research which starts on primary data or field data [18] The approach that I use is a qualitative approach, which is actually a method of research that produces descriptive-analytical, which is expressed by the respondents, both in writing and orally. The Qualitative Approach is an approach that seeks to understand the symptoms in such a way by denying anything that is quantitative.

\subsection{Types and Sources of Data}

Primary data obtained directly from field research through interviews or direct interviews with respondents[19]. Secondary data obtained from official documents, books related to the object of research, research results in the form of thesis reports, theses, dissertations, and laws and regulations. Secondary data can be divided into: a) 
Primary legal materials, namely binding legal materials such as Law No. 1 of 1946 concerning the Criminal Code, 1945 Constitution, Law Number 35 of 2014 concerning Amendments to Law Number 23 of 2002 concerning Child Protection, Law Number 20 of 2003 concerning the National Education System, Law Number 11 of 2012 concerning the Juvenile Justice System and other laws relating to the writing of this research. b) Secondary legal material, is legal material that provides an explanation of primary legal materials. Secondary legal materials used in this research are scientific works, scientific writings, and books related to the object of this research. c) Tertiary legal materials, which are legal materials that provide explanations for primary and secondary legal materials, namely legal dictionaries, Indonesian dictionaries, encyclopedias, the internet, and so on.

\subsection{Data Collection Techniques}

Data collection techniques are divided into 2 (two), namely interviews and documentation. In this study, researchers used interviews and documentation. The interview technique uses a standardized interview using a list of questions as a guide. Then linked with documents that have relevance to the problems to be discussed and supported by the problems. In this research, it is empirical legal research that is supported by empirical legal research, so the prioritized data remains as primary data or field data, secondary data is a supporter or complement [20].

\subsection{Research Location}

This thesis writing data collection is carried out in a. PCY \& SE on Palembang City, South Sumatera b. followed by specific descriptions or statements.
Elementary School on Palembang City, South Sumatra c. Elementary School on, Palembang City, South Sumatra d. Elementary School Palembang on Palembang City, South Sumatra e. Elementary School on, Palembang City, South Sumatra

\subsection{Sampling}

The population is a set of elements or elements that are the object of research and the sample is part of the population taken as a source of data and can represent the entire population. The population to be sampled in this study is in the Kindergarten / SD Division of the Palembang City Disdikpora, under counseling (BK). ) in elementary school. The sample selection technique in this study was carried out by means of purposive sampling, namely by direct appointment by the author to serve as research samples. The author's direct appointment to be used as a research sample is aimed at the Kindergarten / SD section of the Palembang City Disdikpora, at the guidance of Elementary School Counseling (BK),

\subsection{Data Analysis}

In this paper, the authors use qualitative data analysis, by processing and collecting data, data from the interview results are presented in sentence descriptions and then discussed according to the subject matter by relating to laws and regulations and the opinions of experts in accordance with the problems studied.

\subsection{Withdrawal of Conclusions}

Drawing conclusions in a deductive way, namely how to draw conclusions from general statements

\section{RESULTS AND DISCUSSION}

TABLE 1. Protection of Criminal Law for Child Victims of Violence in Primary Schools

Based on the results of documentation and interviews, it was obtained a description of acts of violence perpetrated by children that occurred in Palembang 1 Public Elementary School, 98 Palembang State Elementary School, Palembang Model 2 Madrasah Ibtidaiyah (MIN) 2, Palembang 1 Muhammadiyah Elementary School.

TABLE 2 Description of acts of violence committed by children that occurred in the sample School in Palembang

\begin{tabular}{|c|c|c|c|}
\hline ES1 & ES 98 & MI2 & $\begin{array}{l}\text { Muhammadiyah } 1 \\
\text { Elementary School }\end{array}$ \\
\hline $\begin{array}{ll}\text { - } & \text { MESPersecution } \\
\text { - } & \text { Beatings } \\
\text { - } & \text { Bullying }\end{array}$ & - Persecution & - $\quad$ Bullying & - $\quad$ Fights \\
\hline
\end{tabular}

Data presented in tabular form, which has a research focus in the form of protection of criminal law for victims of violence against children in elementary schools, cases, and causes of acts of violence committed by children in elementary schools, legal prevention in carrying out legal protection for victims of violence against children in 
elementary schools. Legal protection for victims of violence against children in elementary schools in Palembang City is lacking. The school argued that the students committed acts of violence because they lacked attention and affection from their parents or the child's resentment towards their parents that the child brought to school. Of the 4 elementary schools, namely the ES 1 Palembang ES, the 98 Palembang State ES, MI, MES, all of which were subject to violence by children. The school has several cases of violence committed by different children, namely: 1 . Elementary School 1 Palembang, there are 4 cases of violence committed by children, namely, a. $\mathrm{N}$ class $3 \mathrm{c}$ on August 30, 2013, scratched LAN's cheeks b. N S class 3 on 18 December 2013 were beaten by B, A, and N c. R W class 6b on November 282015 threw assault on A. d. J and R classes $4 \mathrm{a}$ and $6 \mathrm{~b}$ on December 10, 2015, attacked AR. 2. Elementary School 98 Palembang, there was 1 case of violence, namely victim S K was slapped and teased by $\mathrm{M} \mathrm{S \text {, }}$ the incident was during community service and mocked each other and then M S slapped S. 3. Madrasah Ibtidaiyah (MIN) 2 Palembang Model there is 1 case of violence, namely, victims D R, W, and $M$ were mugged by $M R$, the incident started during recess $\mathrm{R}$ was annoyed because $\mathrm{D} R$ was not given money then hit $\mathrm{R}$ and was divorced by the teacher 4.

MES, there was 1 case of violence committed, namely, Al I got into a fight with M.S I during the ceremony. The victims of violence committed by children in elementary schools have so far not dared to report to teachers and school principals on the grounds that the school is not aware of acts of violence perpetrated by children in primary schools such as fights, slapping, and bullying. So far, they think that they are just playing games or known as agile children, even though they have caused victims of these actions. Acts of violence committed by children vary widely, ranging from copying taunts, bullying, insulting their parents (making fun of names), over-ordering friends, or boss. Acts of violence committed by children, which I know often occur during recess, where supervision from us teachers is usually done by children who don't pay attention to their parents or people who need to be given more attention. The following is an example of a case that occurred in an elementary school in Palembang City

TABLE 2. Data presentation of cases of violence committed by children in Elementary School 1 Palembang

\begin{tabular}{|c|c|c|c|c|c|}
\hline No & Victim's Name & Actor's Name & Class & Date/ Month & Problem \\
\hline 1. & L AN & N & $3 \mathrm{c}$ & 30 August 2013 & $\begin{array}{c}\text { Clawed } \\
\text { cheek }\end{array}$ \\
\hline 2. & NS & B,A,N & 3 & 18 December 2013 & $\begin{array}{c}\text { Beaten by B, } \\
\text { A, N }\end{array}$ \\
\hline 3. & A & R W & $\begin{array}{c}6 \mathrm{~b} \text { and } \\
6 \mathrm{c}\end{array}$ & $28^{\text {th }}$ November 2015 & $\begin{array}{c}\text { Eating done } \\
\text { by R W }\end{array}$ \\
\hline 4. & A R & J,R & $\begin{array}{c}4 \mathrm{a} \text { and } \\
6 \mathrm{~b}\end{array}$ & $10^{\text {th }}$ December 2015 & $\begin{array}{c}\text { Beaten by J } \\
\text { dan R }\end{array}$ \\
\hline
\end{tabular}

The four acts of violence such as clawing, ganging, and bullying occurred during recess which started from various causes. Like not borrowed stationary, not given money, and seniority in elementary school.

TABLE 3. Data presentation of cases of violence committed by children in 98 Palembang State Elementary Schools

\begin{tabular}{|c|c|c|c|c|c|c|}
\hline No & Victim's name & $\begin{array}{c}\text { Actor's } \\
\text { Name }\end{array}$ & $\begin{array}{c}\text { Witnes } \\
\text { s }\end{array}$ & Class & Date/ Month & Problem \\
\hline 1. & SK & MS & V & $\begin{array}{c}6 \mathrm{a} \text { and } \\
6 \mathrm{~b}\end{array}$ & $\begin{array}{c}6^{\text {th }} \text { October } \\
2016\end{array}$ & $\begin{array}{c}\text { Slapping and } \\
\text { Teasing }\end{array}$ \\
\hline
\end{tabular}

Chronology of Events: The incident occurred during voluntary work on Thursday at school. During the community service, there was mutual mockery between $\mathrm{V}$ and $\mathrm{M} \mathrm{S}$ and SK. After mocking each other, V immediately left Mico and Syamsa. After leaving $\mathrm{V}$ to enter the classroom then $\mathrm{M}$ immediately slapped the face of Syamsa Komariah because M was annoyed at being teased by $\mathrm{S}$ with the words "Mail". Then Syamsa got angry then pinched M's arm. After pinching $\mathrm{S} M$ then replied with a slap on the left cheek. Then Mico went straight to class. The cause of this incident was because it started to mock 
each other because they were offended and then responded with a slap.

TABLE 4. Cases of acts of violence committed by children at Madrasah Ibtidaiyah (MIN) 2 Model Palembang

\begin{tabular}{|l|l|l|l|l|l|l|}
\hline No & $\begin{array}{l}\text { Victim's } \\
\text { name }\end{array}$ & $\begin{array}{l}\text { Actor's } \\
\text { Name }\end{array}$ & Witness & Class & Date/ Month & Problem \\
\hline 1 & D R W M & M R A & M R H & 6 & July 2015 & Bullying \\
\hline
\end{tabular}

Chronology of Events: The incident began during recess D R W Mahardika and MRh were taking a break after they studied. When $\mathrm{R}$ and Rahyan were talking, $\mathrm{R}$ came and met DR and Rahyan who were talking to each other. Then $\mathrm{R}$ asked DR for money and DR didn't want to give money to $\mathrm{r}$. $\mathrm{R}$ was annoyed that he was not given money by dwi rizki.
Then when it was time for school to come home, R stepped DR's foot while he was walking, then DR fell and DR had bruises on his face. Then $d r$ hit $R$. But DR hit R and R and the teacher intervened. The cause of this bullying is due to lack of attention and affection from parents and imbalance when parents give pocket money

TABLE 5 Cases of violence committed by children in Muhammadiyah 1 Palembang Elementary School

\begin{tabular}{|l|l|l|l|l|l|}
\hline No & Victim's name & Actor's Name & Class & Date/ Month & Problem \\
\hline 1. & A I & M SI & III B & $21^{\text {st }}$ August 2016 & $\begin{array}{l}\text { Fighting during the } \\
\text { Ceremony }\end{array}$ \\
\hline
\end{tabular}

The reason for the occurrence of fights during the ceremony is usually due to fighting over the line, teasing his friend in front of him, and taking his friend's hat. Understanding scratching, beating up, bullying as acquaintances to students in general Researchers have to use the Indonesian equivalent of words several times, namely delinquency or violence. The teacher assesses that violence and recognition in schools such as fighting, bullying, and beatings are still at a reasonable level or do not exceed the limit, or as an agile child. Even introducing them is a part of student development.

\section{CONCLUSION}

Forms of protection for children who are victims of bullying:Rehabilitation efforts that are carried out within an institution or outside of an institution, these efforts are made to restore mental, physical, and other conditions after experiencing very deep trauma as a result of a criminal event he has experienced. Efforts to protect the victim's identity from the public, these efforts are made to ensure that the identity of the child who is the victim or the victim's family is not known by others, with the aim that the good name of the victim and the victim's family is not tainted. Efforts to provide safety guarantees for victim witnesses, namely children and expert witnesses, both physically, mentally and socially from threats from certain parties, are made to ensure that the case process runs efficiently.

\section{REFERENCES}

[1] Tukiman.Murni, Protection of Children Against All Forms of Neglect,Violence and Exploitation, Bina Cipta, Jakarta, 1984

[2] Irsan, Koesparmono, Law and Human Rights, Yayasan Brata Bhakti,Jakarta, 2009

[3] Fanani, Zainudin, Educational Guidelines, Tiga Serangkai, Solo, 2011.

[4] Wibowo, Antonius, PS, 2018, Cyber Bullying Among Law Student: How They Deal With It, Understand and Apply The Law, ICoLGaS, SHS Web of Conferences 54, 07005

[5] Halim, Ridwan, Education Crime in Indonesian Criminal Law Principles, Ghalia Indonesia, Jakarta, 1986

[6] Suyanto Bagong, Child Social Problems, Kencana, Jakarta, 2010

[7] Thalib, Syamsul, Bahri, Educational Psychology Based on Applicative Empirical Analysis, Kencana Prenada Media Group, Jakarta, 2010

[8] Yousafzai, Abdul, Wahab, 2018, Child Abuse: Are We Doing Enough To Prevent It ?, Khyber Med Univ J, 10(1):1-2.

[9] Chomaria, Nurul, Abusing Children Without Realizing It: 12 Mistakes That Happen In Educating Children, PT. Aqwam Media Profetika, Solo, 2010,

[10] Sutanto, Criminology Study on Violence Against Women, PKBI, Yogyakarta, 2006 
[11] Atmasasmita, Romli, Juvenile Justice in Indonesia, Mandar Maju, Bandung, 1995

[12] Nasir, Hedir, Religion and the Crisis of Modern Humanity, First Printing, Pustaka Pelajar, Yogyakarta, 1997

[13] Nasriana, Protection of Criminal Law for Children in Indonesia, Raja Grafindo Persada, Jakarta, 2012

[14] Wahid, Abdul, and Irfan, Muhammad, Protection of Victims of Sexual Violence (Advocacyfor Women's Human Rights), Rafika Aditama, Bandung, 2001

[15] Kartono, Kartini, Social Pathology, Grafindo Persada, Jakarta, 2010

[16] Ille, Gabrielle, Mann, Robert, E, dkk, 2014, Suicidality, Bullying and Other Conduct and Mental Health Correlates of Traumatic Brain Injury in Adolescents, department of Community Health and Epidemiology and Department of Emergency Medicine, Dalhousie University, Halifax, Nova Scotia, Canada, April 2014 | Volume 9 | Issue 4

[17] Nguyen, Hoang, Thuy, Linh, Nakamura, Keiko, Seno Kaoruko, 2020, Relationships among cyberbullying, parental attitudes, self-harm and suicidal behavior among adolescents: results from a school-based survey in Vietnam, Nguyen et al. BMC Public Health, 20:476

[18] Efendi. Jonaedi and Ibrahim. Johny, Normative and Empirical Legal Research Methods, K Kencana, Jakata, 2016

[19] Asofa, Burhan, Legal Research Methods, Rineka Cipta, Jakarta, 2002

[20] Soekanto, Soerjono \& Mamuji, Sri, Normative Legal Research A Short Action, Radjawali Pers, Jakarta, 1990 